\title{
Revisitando os clássicos da moderna teoria de finanças: uma análise
}

\begin{abstract}
A Moderna Teoria de Finanças teve seu desenvolvimento durante os últimos 60 anos, com as contribuições de diversos autores e a formulação de várias teorias. Entretanto, devido a um tradicionalismo presente na área e de uma restrição ligando a área de finanças a imensas fórmulas matemáticas e econométricas, muitos pesquisadores desistem de compreender as mais variadas facetas contidas nesta área. Partindo desta premissa, buscou-se no presente artigo apresentar os principais clássicos da Moderna Teoria de Finanças em uma forma compreensível a qualquer área do conhecimento. Neste artigo, são descritas as contribuições de Markowitz (Seleção de Portfólios), os estudos de Modigliani e Miller (Teoria da Estrutura e do Custo de Capital), o desenvolvimento do CAPM por meio dos estudos de Sharpe, Lintner e Mossin, as contribuições de Fama e Brown (Hipótese de Mercados Eficientes), a quebra de paradigma trazida por Tversky e Kahneman (Finanças Comportamentais), além da Teoria da Agência, conforme estudos de Jensen, Meckling e Myers. Revisitar os clássicos da Moderna Teoria de Finanças comprovou a transformação sofrida pela área e demonstra a todos os pesquisadores e interessados, que esta área, tida como tradicional durante vários anos, está agora aberta a novas ideias, a novos paradigmas e a todos os tipos de contribuições.
\end{abstract}

Palavras-chave: Finanças; Teoria Clássica; Finanças Modernas; Epistemologia; Paradigmas.

\section{Revisiting the classics of the modern finance theory: a paradigmatic analysis}

\begin{abstract}
The Modern Finance Theory had its development over the past 60 years, with contributions from several authors and the formulation of various theories. However, due to a traditionalism in this area and a restriction linking the Finance area to large mathematical and econometrics formulas, many researchers give up to understand the various facets present in this area. Starting from this premise, the objective of this paper is to present the main classics of Modern Finance Theory in a form understandable to any area of knowledge. In this paper, we describe the contributions of Markowitz (Portfolio Selection), the studies of Modigliani and Miller (Theory of Structure and Cost of Capital), the development of the CAPM by Sharpe, Lintner and Mossin, the contributions of Fame and Brown (Efficient Market Hypothesis), the paradigm rupture by Tversky and Kahneman (Behavioral Finance), and the Theory of Agency, according to Jensen, Meckling and Myers studies. Revisiting the classics in finance showed the transformation of the area and demonstrates to all researchers and interested, that this area, considered traditional for several years, is now open to new ideas, new paradigms and all types of contributions.
\end{abstract}

Keywords: Finance; Classical Theory; Modern Finance; Epistemology; Paradigms.

Topic: Finanças Empresariais

Reviewed anonymously in the process of blind peer.
Received: 03/05/2017

Approved: 03/07/2017

\section{Danilo de Melo Costa}

Centro Universitário UNA, Brasil

http://lattes.cnpq.br/3830651638287635

danilo_mcosta@yahoo.com.br

\section{Referencing this:}

COSTA, D. M.. Revisitando os clássicos da moderna teoria de finanças: uma análise. Revista Brasileira de Administração Científica, v.8, n.2, p.16-41, 2017. DOI: http://doi.org/10.6008/SPC2179$\underline{684 X .2017 .002 .0002}$ 


\section{INTRODUÇÃO}

Afinal, o que é um clássico? Para Calvino (2007) “Os clássicos são aqueles livros dos quais, em geral, se ouve dizer: "Estou relendo [...]" e nunca "Estou lendo [...]" É muito comum aplicar tal definição quando se refere a importantes livros, sobretudo de literatura, que deixaram marcado seu espaço na história. Entretanto, na comunidade acadêmica, é possível identificar vários artigos científicos que se enquadram em todas as definições de um 'clássico', haja vista sua intensa contribuição para o desenvolvimento de um campo de pesquisa.

Na grande área das Ciências Sociais Aplicadas, dentro da área de Administração, existem vários artigos (e autores) clássicos que são muito importantes de serem estudados. Estes são divididos em várias sub-áreas, como a sub-área de Organizações e Sociedade, Estratégia, Marketing, Logística, Finanças, dentre outras. Mesmo com sua importância 'ímpar' para o desenvolvimento de teorias que são estudadas, além de servirem de referências para vários avanços no respectivo campo de pesquisa, os clássicos acabam por ser mais citados do que lidos, e esta interpretação da interpretação (da interpretação) pode fazer com que a essência daquele clássico desapareça em grande parte dos trabalhos.

(...) nunca será demais recomendar a leitura direta dos textos originais, evitando o mais possível bibliografia crítica, comentários, interpretações. A escola e a universidade deveriam servir para fazer entender que nenhum livro que fala de outro livro diz mais sobre o livro em questão; mas fazem de tudo para que se acredite o contrário. (CALVINO, 2007)

Tal como apresentado por Calvino (2007), a maneira como se lê um clássico está associada à maturidade do leitor. Na juventude, buscam-se respostas rápidas, que acabam por ser fornecidas por simples manuais que compilam e interpretam os grandes clássicos (caso estes estejam presentes), mas que fornecem as informações de uma maneira muito superficial. Na idade madura, a leitura é mais profunda, buscando apreciar os mais variados detalhes.

Ter a condição de apreciar um clássico pela primeira vez, com o senso crítico mais apurado, é um privilégio inigualável. Talvez seja este o motivo de tais obras serem apresentadas com mais frequência nos cursos de Pós-Graduação Stricto-sensu do que nos demais cursos. Embora o questionamento deva nortear toda a academia, ele acaba por ser mais latente nos cursos de Pós-Graduação do que nos cursos de Graduação, dessa forma, o aluno tem a oportunidade de ser apresentado a um clássico e formar sua própria opinião a respeito dos escritos de Calvino (2007).

Para Calvino (2007), "Toda releitura de um clássico é uma leitura de descoberta como a primeira.", porque "Um clássico é um livro que nunca terminou de dizer aquilo que tinha pra dizer". Logo, mesmo que um leitor tenha sido apresentado a um clássico na juventude, a releitura trará novas descobertas que ele não foi capaz de perceber. É como se um clássico fosse capaz de "captar" a maturidade de seu leitor. Por mais que se tenha ouvido dizer a respeito daquele clássico, a leitura revelará sempre fatos novos, inesperados, inéditos, pois ficará a cargo do próprio leitor realizar a interpretação.

Ainda que se leiam vários estudos construídos com base em grandes clássicos, quando se identifica um clássico, encontra-se seu posicionamento genealógico junto às obras previamente lidas. Modernas teorias de vários campos de estudo foram construídas com uma base sólida de artigos clássicos. Deve-se 
perceber esta construção durante a leitura de um importante clássico. Todavia, é importante ressaltar que um clássico não é inerentemente uma obra antiga. O leitor deve saber dosar o antigo e o novo até para entender a influência de um estudo em relação ao outro (CALVINO, 2007).

A partir desta explanação, este artigo tem como objetivo revisitar os principais clássicos da Moderna Teoria de Finanças, que é considerada por muitos uma sub-área puramente tradicional. A compreensão, além dos simples manuais, se faz necessária para compreender como se formou esta moderna teoria, de forma a se quebrar o paradigma de que finanças é um campo de conhecimento restrito somente aos pesquisadores da área.

Para tanto, busca-se descrever de uma forma compreensível a qualquer área do conhecimento, as contribuições clássicas de Markowitz (1952), Modigliani et al. (1958, 1963), Miller et al. (1961), Miller (1988), Sharp (1964), Lintner (1965), Mossin (1966), Fama (1970, 1991), Brown (2011), Tversky et al. (1974), Jensen et al. (1976), Jensen (1986) e Myers (1977) para a Moderna Teoria de Finanças, além de apresentar indicações de teorias complementares às obras estudadas.

\section{METODOLOGIA}

Por se tratar de uma pesquisa pura (teórica), cujo intuito é desmistificar alguns paradigmas presentes nas teorias de finanças, seu processo de estruturação se embasou nos estudos relacionados ao tema, buscando a construção de um arcabouço teórico pautado na totalidade histórica e nas principais transformações ocorridas na chamada "Moderna Teoria de Finanças" nas últimas décadas. O objetivo da respectiva estruturação foi enquadrar a teoria estudada, por meio de pontos de vista, aspectos e ângulos de forma variada, estabelecendo conexões com o intuito de se buscar o estado da arte (MINAYO, 1998).

O caráter qualitativo está presente devido à compreensão e interpretação dos dados coletados por meio de pesquisa bibliográfica, mediante material já desenvolvido e publicado sobre o tema a ser pesquisado. A pesquisa bibliográfica contemplou a leitura, análise e interpretação de publicações avulsas de todo o mundo, com destaque para artigos e autores considerados clássicos no desenvolvimento da moderna teoria de finanças nas últimas décadas (GIL, 1995). Dentre os autores, ressalta-se: Markowitz (Seleção de Portfólios), Modigliani e Miller (Teoria da Estrutura e do Custo de Capital), Sharpe, Lintner e Mossin (CAPM), Fama e Brown (Hipótese de Mercados Eficientes), Tversky e Kahneman (Finanças Comportamentais) e Jensen, Meckling e Myers (Teoria da Agência).

A partir de então, os dados da pesquisa bibliográfica foram submetidos a uma triagem, com o objetivo de se estabelecer um plano de análise e interpretação do material coletado, realizando fichamentos dos achados que foram posteriormente correlacionados. A análise dos dados pode ser considerada como o momento de se compreender os achados buscando negar ou validar os objetivos traçados no início da pesquisa (YIN, 1989). Tendo como referência esta premissa, após a coleta de dados, as informações foram compiladas selecionando as de maior interesse, para que posteriormente fosse realizada a análise interpretativa crítica de modo a elucidar, para as diversas áreas do conhecimento, os principais conceitos por trás da moderna teoria de finanças. 


\section{DISCUSSÃO TEÓRICA}

A presente seção busca apresentar os principais clássicos da Moderna Teoria de Finanças em uma forma compreensível a qualquer área do conhecimento. Inicialmente, são descritas as contribuições de Markowitz (Seleção de Portfólios), seguido dos estudos de Modigliani e Miller (Teoria da Estrutura e do Custo de Capital), e depois o desenvolvimento do CAPM por meio dos estudos de Sharpe, Lintner e Mossin. Posteriormente, são descritas as contribuições de Fama e Brown (Hipótese de Mercados Eficientes), a quebra de paradigma trazida por Tversky e Kahneman (Finanças Comportamentais) e finalmente a Teoria da Agência, conforme estudos de Jensen, Meckling e Myers.

\section{O pai da Moderna Teoria de Finanças}

Em todas as áreas, dos mais variados segmentos, importantes decisões são tomadas dia após dia. Entretanto, na maioria dos casos, não é possível estar totalmente certo se a decisão tomada será a melhor e principalmente se ela trará os resultados esperados, por esse motivo, passa então a ser fundamental reduzir ao máximo a incerteza da respectiva decisão, visando encontrar caminhos cada vez mais eficientes para se chegar aos melhores resultados.

Quando se analisa a área de Finanças, as decisões envolvendo investimentos (No que investir? Como investir? Quando investir?) são norteadas de um alto grau de incerteza, pois o investidor nunca sabe, exatamente, qual o retorno esperado daquele investimento, tal como se observa no exemplo de lquipaza et al. (2009): “(...) se o preço atual de uma ação refletir toda informação disponível, então, seus movimentos de preços futuros só serão ajustados por meio de nova informação, que, em função disso, é por definição imprevisível".

Quando a incerteza está relacionada à verificação de um determinado evento que pode representar aspectos negativos nos diversos resultados esperados, significa que a decisão está sendo tomada sob uma situação de risco, e quando se trata de finanças (algo que envolve, na maioria dos casos, recursos monetários), vários investidores são "avessos ao risco", pois exigem (ou esperam), um retorno em todo investimento realizado. É ai que entra a Teoria da Seleção de Portfólio (MARKOWITZ, 1952).

Nos estudos de Markowitz (1952), pôde-se perceber que o pesquisador nunca pretendeu eliminar por completo o risco, mesmo porque, existem infinitas variáveis que podem influenciar positivamente ou negativamente qualquer investimento, situações inclusive que a matemática não é capaz de prever. Markowitz (1952) busca então auxiliar na seleção de Portfólios de ativos ótimos, principalmente aos investidores avessos ao risco, utilizando para isso, fórmulas econométricas.

Ao elaborar sua carteira de investimentos, qualquer investidor passa por duas etapas: Na primeira etapa, ele usa sua experiência para observar o que se passa no mercado e define sua expectativa sobre o comportamento futuro dos ativos disponíveis. Na segunda etapa, ele já tem esta expectativa traçada e inicia sua escolha pela melhor carteira de investimento. Levando em conta que a incerteza com seus prejuízos ou lucros associados impera principalmente nesta segunda-etapa (pois é neste momento que o investidor irá inserir seus recursos), Markowitz (1952) foca seu estudo então nesta etapa do processo. 
Dentro da área de finanças, é de conhecimento geral de que um indivíduo quer sempre maximizar suas riquezas. Para maximizá-las por meio de investimentos, ele terá que decidir quais ativos serão mais rentáveis dentre todos os disponíveis no mercado (moeda, bônus, ações, obras de arte, terras, casas, máquinas, etc.). Markowitz (1952) sugere a diversificação de ativos no Portfólio, ajudando os indivíduos a compreenderem quais ativos que valem a pena receber investimento.

O investidor pode aplicar seu capital em vários ativos diferentes, que gerarão retornos (lucro) e variâncias (riscos) distintos, formando seu portfólio. Inicialmente, o objetivo é de calcular o retorno dos ativos, para que se consiga perceber o retorno daquele Portfólio de ativos. Como os estudos sugerem a diversificação de ativos, a melhor maneira para se descobrir o retorno esperado é por meio de um somatório, em que se utiliza o capital que foi investido junto dos retornos esperados dos respectivos ativos.

Para se descobrir o risco, busca-se compreender a variância daquele portfólio encontrado. Neste caso, a variância (que é o desvio padrão ao quadrado), compreenderá o risco daquela carteira de ativos (ou portfólio). Considerando esta relação retorno-variância, proposta por Markowitz (1952), pode-se fazer inúmeras combinações de ativos, gerando vários portfólios com retornos e variâncias distintas.

Os portfólios que possuírem o melhor retorno, dado um nível de variância, ou os que apresentarem menor variância, dado um nível de retorno são chamados de eficientes. Como estes portfólios são agrupados, é possível se localizar uma "Fronteira Eficiente", que ajudará ao tomador de decisões perceber qual o melhor portfólio de ativos ele deve investir naquele momento:

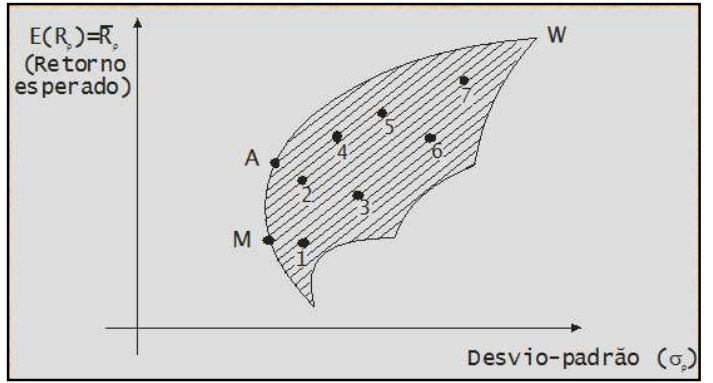

Figura 1: Fronteira Eficiente. Fonte: Farrell Junior (1997).

O grande avanço no modelo de Markowitz é que, neste modelo, é possível construir carteiras de investimento em que o risco do portfólio é inferior ao ativo de menor risco da carteira. O modelo mostra ainda que a maior parte de combinações eficientes são formadas por ativos diversificados. Estes importantes resultados, que contribuíram para o avanço e criação de outros estudos, fazem do artigo Portfolio Selection um dos maiores clássicos da moderna teoria de finanças.

\section{A Teoria da Estrutura e do Custo de Capital e as Principais Contribuições de Modigliani e Miller}

Conforme observado nos estudo de Markowitz (1952), que antecedem os estudos de Modigliani e Miller, existia-se uma necessidade de se reduzir os riscos quando se fosse investir em determinados ativos, sobretudo para auxiliar aqueles investidores "avessos ao risco". A ideia é a de conhecer o retorno esperado e o risco de uma carteira de ativos (MARKOWITZ, 1952). 
Modigliani e Miller contribuem desenvolvendo estudos clássicos, pois apresentam inovações no que se refere ao Custo de Capital, Finanças Corporativas e a Teoria de Investimento, visando clarear ainda mais o até então obscuro mundo dos investimentos financeiros. Tais estudos passam a se tornar referência obrigatória para os interessados em se aprofundar nestes temas.

Miller et al. (1961) abrem sua discussão com uma pergunta que pode ser até considerada uma provocação. Afinal, o que seria um "Custo de Capital”? Esta pergunta se faz totalmente pertinente como uma excelente introdução, pois o capital não é algo linear, ele pode ser obtido de diversas formas, como por exemplo, um empréstimo puro com juros pré-definidos, até as ações, em que os investidores têm direito ao rateio proporcional do lucro que é totalmente incerto (ou seja, a variável incerteza continua norteando as decisões financeiras) (MILLER et al., 1961).

A partir do momento em que as decisões são tomadas tendo como premissa a racionalidade do indivíduo (ou pelo menos é o esperado), os investimentos que serão realizados pelas empresas acabam por obedecer dois importantes critérios: e maximização do lucro, pois a empresa espera aumentar sua riqueza, e consequentemente a riqueza de seus proprietários; e maximização de seu valor de mercado, principalmente se for considerada a questão da concorrência em um mercado cada vez mais competitivo.

Ao se considerar a incerteza em um caso de maximização do lucro, a expectativa não será somente de um ponto e sim de uma distribuição de probabilidade de ocorrência, tendo em vista que a utilização de dívida para financiar o investimento necessitaria aumentar a expectativa de retorno dos proprietários. Frente a esta situação, as opções de financiamentos e investimentos deveriam ser confrontadas e classificadas apenas nos termos da função utilidade dos acionistas, que é completamente subjetiva. Afinal, não é possível saber as preferências de risco e retorno de cada acionista, o que torna esta questão sem resposta.

O critério de maximização de seu valor de mercado, definido anteriormente, traz uma solução para a questão proposta pelos próprios autores. Deve-se então avaliar se o projeto, considerando obviamente seu financiamento, elevará o valor de mercado das ações da companhia. Pensando desta forma, não importará a preferência de apenas um acionista, mas do mercado como um todo. Tal premissa se confirma, pois se caso o acionista não estiver satisfeito com as decisões, ele terá total liberdade de vender suas ações a qualquer momento, o que facilita todo o processo.

Algumas simplificações propostas por Modigliani et al. (1958) ajudam na composição da Teoria dos Investimentos: todos os ativos físicos são somente das empresas: deve-se haver esta separação no que se refere aos ativos de cada uma das organizações; elas podem ser financiadas apenas com capital próprio; todos os acionistas possuem expectativas de retorno homogêneas; e os gestores atuam dentro do esperado pelos acionistas da respectiva organização e, dessa forma, não importa qual a proporção de distribuição de dividendos e lucros retidos.

Observando as condições impostas, as empresas passam então a ser divididas em classes, tendo como referência a incerteza de seus fluxos (que representa o risco). Como os retornos das empresas que estão em uma mesma classe são equivalentes, uma ação pode ser perfeitamente substituída por outra ação 
que tenha a mesma classe. Dessa forma, a proporção de expectativa de retorno pelo preço de uma ação (cujo o nome é taxa de expectativa de retorno) é a mesma para todas as empresas que estão em mesma classe.

Todavia, Modigliani et al. (1958) apresentam uma provocação, quando relatam que existe a possibilidade das empresas contraírem dívidas, e isto fatalmente alterará a distribuição de probabilidades dos retornos, pois fará com que as empresas da mesma classe de risco tenham perspectivas diferentes de retorno, em função de sua alavancagem ${ }^{1}$.

Com o intuito de comprovar sua assertiva, Modigliani et al. (1958) iniciam a explanação levando em conta dois importantes pressupostos: todas as dívidas possuem retornos constantes e certos; e os títulos de dívidas podem ser comercializados em um mercado perfeito. Tais assertivas dão base para três importantes proposições, que norteiam o estudo da Teoria do Investimento.

$\mathrm{Na}$ 1a Proposição, o valor total da empresa (que é obtido meio a soma do valor de mercado da dívida com o valor de mercado das ações), é igual à expectativa de retorno dos ativos da empresa dividido pela taxa de expectativa de retorno apropriada à classe ao qual a empresa está inserida. Tendo como base está proposição, a forma de financiamento da empresa não irá interferir em seu valor final, apenas nas expectativas de retorno de seus ativos físicos.

Caso a 1a Proposição não se confirme, os investidores terão a opção de vender as ações, que em tese estarão com o valor acima do normal, e poderão comprar outras ações referentes a empresas que estão situadas na mesma classe de risco da respectiva empresa. Esta prática tende a abaixar os preços das ações que estão sendo vendidas naquele momento, enquanto sobe o preço das ações que estão sendo compradas, culminando assim em um equilíbrio. A justificativa para esta proposição é a de que as empresas não precisam contrair dívidas, uma vez que os investidores têm a possibilidade de contratar suas dívidas de maneira individual e dessa forma, decidirem por si mesmos (considerando os juros iguais pra todos).

Na 2a Proposição, tem-se que o endividamento irá elevar o risco das empresas, por este motivo, os proprietários irão exigir um retorno maior, que seja diretamente proporcional ao risco advindo pela alavancagem. O curioso nesta situação é que, analisando de uma maneira simplista, quanto mais dívidas contrair uma empresa, maior será a taxa de juros cobrada por um empréstimo. Os juros maiores tendem então a diminuir os recursos que iriam para os acionistas, fazendo com que se reduzam suas expectativas de retorno, de maneira que se diminua o valor de suas ações. Entretanto, considerando a premissa de que o valor total de uma empresa é a soma do valor de mercado das dívidas mais o valor de mercado das ações, seu total se manterá.

Segundo Modigliani et al. (1958), ainda que a taxa de juros dos empréstimos seja menor do que a expectativa de retorno dos acionistas (na maioria dos casos), o custo médio ponderado de capital reduzirá, pois o maior risco elevará a exigência dos acionistas na mesma proporção, mantendo dessa forma o Custo Médio Ponderado do Capital inalterado.

${ }^{1}$ Usar todos os recursos disponíveis para melhorar sua rentabilidade ou a rentabilidade de seu negócio. Saber usar o que você não tem, com o objetivo de conquistar o que você quer. 
Tais estudos de análise das implicações da teoria supracitada sobre a política de Investimentos culminam em uma 3a Proposição. Afinal, caso as empresas ajam de acordo apenas com os interesses dos acionistas, elas somente admitirão projetos de investimento em que a taxa de retorno for igual ou superior a expectativa de retorno dos proprietários, sem considerar a maneira como o investimento é financiado.

Com isso, Modigliani et al. (1958) destacam o fato de que a 3a Proposição não implica que os acionistas não tenham preferência na forma de financiamento, tendo em vista que um investimento apropriado (que irá provocar um aumento nos preços das ações no futuro) pode não ser interessante que seja financiado com capital próprio ao preço atual.

Fica clara a relevância das três proposições no que se refere à Teoria dos Investimentos. É interessante ressaltar que Miller et al. (1961) deixam em aberto o interesse em continuar os estudos nesta área, abrindo inclusive a possibilidade para que outros interessados possam compartilhar com estes estudos, algo que inevitavelmente acontece em trabalhos futuros, inclusive dos próprios Modigliani e Miller, que após discutirem as consequências das políticas de investimento e financiamento no retorno das empresas, levantam uma grande polemica com uma análise a respeito das influências das políticas de dividendos (MILLER et al., 1961), outro clássico desenvolvido por Miller et al. (1961).

Tendo como premissa uma perspectiva tradicional, as políticas de dividendos são consideradas relevantes na determinação do valor das ações no mercado e no custo de capital das empresas, pois havia a perspectiva das empresas repassarem o lucro junto do pagamento dos dividendos, algo que seria mais interessante aos investidores do que receberem apenas os ganhos de capital, que passam a ter um valor inferior, tendo como base a incerteza que impera sobre o recebimento destes rendimentos futuramente.

Entretanto, os estudos de Miller et al. (1961), contestam esta teoria, ao afirmar que o valor da empresa não depende das políticas de dividendos. Esta afirmação nasce baseada nas políticas de investimentos das organizações, que são determinadas apenas pelas perspectivas de fluxos de caixa futura, não havendo qualquer relevância na maneira que estes fluxos poderiam ser alocados junto aos dividendos ou lucros retidos, tendo em vista que esta alocação não gera alteração nos fluxos de caixa.

Esta teoria passa a ser apoiada pelo que se chamou de 'mercado perfeito' (um mercado em que dentre todas as transações de ações, nenhuma é relativamente ampla para causar impacto em um preço vigente, além disso, a informação passa a ser a mesma para todos os investidores que não precisam pagar por elas, sendo todos racionais e com o objetivo único de maximização de riqueza).

A partir da concretização dos mercados perfeitos, a expectativa é que haveria uma flutuação nos preços dos ativos em torno de seu valor próprio, em um cenário que informações novas poderiam ocasionar rapidamente mudanças no valor previamente estabelecido, mas o imediato preço do ativo iria flutuar de maneira aleatória. Isto faria com que os mercados financeiros perdessem sua previsibilidade (MILLER et al., 1961).

Miller et al. (1961) apresenta que, para se garantir a não relevância dos dividendos, algumas premissas deviam ser satisfeitas: eliminação dos impostos sobre o rendimento tanto de pessoas físicas quanto de pessoas jurídicas; eliminação dos custos para lançamento de ações na bolsa (no mercado); inexistência 
dos efeitos da política de endividamento sobre o capital da empresa, e, por conseguinte, os benefícios da dívida ainda não eram considerados; e inexistência de assimetria informacional.

Este estudo foi fundamental para desencadear mais estudos dentro da moderna teoria das finanças, não apenas de cunho teórico como também de cunho prático, tendo em vista que ele instigou vários pesquisadores a realizar pesquisas empíricas tentando comprovar sua validade. Tais estudos foram fundamentais para se desenvolver ainda mais as pesquisas na área de finanças, e também para Modigliani e Miller deixarem, de fato, seus nomes marcados na história dos estudos desta área.

Em 1963, cinco anos após a publicação do artigo The Cost of Capital, Corporation Finance, and the Theory of Investment, os próprios Modigliani et al. (1963) publica um novo artigo com o objetivo de corrigir um erro neste trabalho. A correção está relacionada com a parte no artigo em que eles afirmam que o valor de mercado das empresas, em cada classe de risco, deve ser proporcional à sua expectativa de retorno líquido de impostos, sendo esta expectativa a soma dos juros pagos e a expectativa líquida dos ganhos dos acionistas.

Esta afirmativa estava errada, pois ainda que uma empresa tivesse uma perspectiva de retorno duas vezes maior que a de outra empresa (na mesma classe de risco), não quer dizer que o retorno real após os impostos incorridos sobre a primeira empresa será sempre o dobro dos impostos incorridos sobre a segunda empresa, se as duas empresas possuem diferentes graus de alavancagem. Dessa forma, o ajustamento sobreposto no artigo de 1963, acontece quando se aplica a relação do rendimento após os impostos e o custo de capital próprio, obtendo, portanto, a relação entre o lucro líquido após os impostos e o valor de mercado da empresa.

Esta correção tem uma implicação direta no aumento do rendimento após os impostos sobre o capital próprio com o aumento da alavancagem da empresa, que foi menor se comparada com a anteriormente apresentada. Esta retificação permite avaliar melhor a estrutura de capital a longo prazo, para se conter a adequação do capital próprio e o dos investimentos, de maneira que se conheça a alavancagem da empresa, mensurando, dessa forma, o custo de capital adequado para as decisões de investimento da empresa.

Neste novo estudo, nota-se que os benefícios da dedutibilidade tributária dos juros dos empréstimos são maiores do que os autores sugeriram inicialmente. Eles comprovam por meio de fórmulas matemáticas que a variância da distribuição dos retornos após os impostos é menor se a alavancagem for maior. Além do mais, no artigo lançado anteriormente (MILLER et al., 1961), eles levaram em consideração que somente os benefícios fiscais originados da dedutibilidade dos juros possuíam como vantagem melhorar o resultado do fluxo de caixa. No artigo corrigido (MODIGLIANI et al., 1963), pode se observar que, além disso, existia outra importante vantagem: tais benefícios fiscais compõem-se em fluxos certos, assim sendo, os mesmos não podem ser descontados por uma taxa que considere um prêmio pelo risco, porém, devem ser descontados por uma taxa livre de risco.

De toda forma, nota-se que o efeito da alavancagem no valor da companhia é apenas uma questão de dedutibilidade dos juros (na visão tradicional, era considerado que o endividamento poderia reduzir o custo de capital da organização). Uma consideração importante de ser ressaltada é a de se trabalhar com os 
benefícios fiscais. Mesmo que seja possível financiar um investimento em $100 \%$ utilizando apenas capital de terceiros, não se deve considerar esta possibilidade por dois motivos: as restrições impostas pelos credores; e alguma situação inesperada pode fazer com que se exija um montante adicional de dinheiro emprestado (afinal, no mundo das finanças, sempre se lida com incertezas e com o imponderável) (MODIGLIANI et al., 1963).

Porém, em um longo prazo, as empresas tendem a possuir uma estrutura de capital alvo que pode maximizar seu valor. Dessa forma, o estudo considera que o custo de capital relevante, e, deste modo, adequado ao desconto dos fluxos de caixa futuros para avaliação de projetos de investimento é a média ponderada entre os custos de capital próprio e de terceiros.

O artigo delineia sua conclusão tratando de um assunto extremamente polêmico e controverso (aplicado facilmente ao século XXI), que é a questão de se utilizar dívidas em seu financiamento. Mesmo que haja certa vantagem nesta utilização, as empresas não devem utilizar o montante máximo de capital de terceiros em sua estrutura de capital, tendo em vista que existem várias outras formas de financiamento, como por exemplo, os lucros retidos, que em vários casos, se apresentam mais baratos, além das limitações impostas pelos credores.

Quatorze anos após a publicação de 1963, no ano de 1977, Miller apresenta um estudo clássico, independente, no qual o assunto principal são as dívidas e os impostos. No início do artigo, o autor apresenta resultados de estudos anteriores, assegurando que dado uma variedade de oportunidades ofertadas às empresas, o valor de mercado das mesmas deve ser livre de sua estrutura de capital. Tal assertiva é inserida sobre a prerrogativa de comportamento racional e dos mercados perfeitos (MILLER, 1977).

Miller (1977) apresenta que alguns pesquisadores discordaram da afirmação dos mercados perfeitos, racionalidade e de que a alavancagem não influência o custo de capital, publicados em seus estudos junto de Modigliani (MODIGLIANI et al., 1958, 1963; MILLER et al., 1961). Já algumas afirmações apresentam que uma companhia pode ter seu valor aumentado por meio do uso da dívida, tendo em vista que os juros podem vir a ser deduzidos do imposto de renda das empresas.

Uma das características marcantes deste estudo é a variável do custo de falência, que deixa subentendido se tratar do valor dos juros pagos. A mensuração do custo de falência pode ser pelos juros de alavancagem. Para diversos pesquisadores, os custos de falência tendem a se equilibrar com os ganhos advindos do financiamento da dívida do imposto de renda. Entretanto, em um cenário em que os juros são integralmente dedutíveis no cálculo do imposto de renda corporativo, o valor da companhia tende a ser livre da sua estrutura de capital. A utilização do financiamento por dívidas para os custos de falência é uma assertiva que não é descartada por Miller (1977), tanto que em seu estudo junto de Modigliani (MODIGLIANI et al., 1958), os custos de falência foram discutidos e trabalhados.

Entretanto, uma dúvida norteava este tema. Se a estrutura ótima de capital era apenas uma questão de equilibrar as vantagens fiscais contra os custos de falência, qual motivo fez com que as estruturas de capital das empresas mudassem minimamente no decorrer dos anos? Miller (1977) percebe então que a evolução da razão do débito sobre os ativos das empresas diferia entre os anos 1920 e 1950, entretanto, neste mesmo 
período, o valor dos impostos de renda haviam quadruplicado, logo, se o valor do débito viesse a influenciar o valor da empresa, certamente o aumento dos impostos iria implicar em um acréscimo do financiamento por dívidas, tendo em vista que quanto maior as dívidas, maior os ganhos pela dedução dos juros.

Miller (1977) acredita que a dependência da dívida na estrutura de capital, por exemplo, implica uma companhia a pagar uma parte considerável de seus rendimentos na forma de juros passivos aos proprietários na esfera do imposto de renda pessoal. Miller (1977) questiona o motivo dos economistas insistirem em desenvolver modelos que adotam um comportamento puramente racional por parte das companhias.

Os estudos de Miller (1977) comprovam que existe um ponto de equilíbrio da dívida das empresas agregadas, e consequentemente, um equilíbrio da razão de endividamento para todo setor empresarial. Empresas na sequência de uma estratégia de baixa alavancagem na época do estudo (como o caso da IBM e da Kodak, citadas inclusive durante o artigo), devem descobrir um mercado entre os investidores nos suportes de impostos elevados. As empresas que optarem por uma estratégia de alta alavancagem (como exemplo, apresenta-se o setor de eletricidade e energia), tendem a descobrir uma clientela natural para os seus valores mobiliários, no outro extremo da escala.

Dessa forma, o valor de qualquer empresa, em equilíbrio, seria independente de sua estrutura de capital, não obstante a dedutibilidade dos juros no cálculo do rendimento líquido. As taxas de juros de mercado precisam ser extrapoladas para pagar os impostos do cotista marginal, em que a taxa de imposto em equilíbrio será igual à taxa corporativa. Finalmente, além das contribuições por hora apresentadas, outros trabalhos clássicos também possuem um papel muito importante para evolução deste tema e merecem ser estudados (MILLER, 1988; ANGELO et al., 1980; MILLER et al., 1985; WOOLRIDGE et al., 1895).

\section{A Origem do Modelo CAPM e as contribuições de Sharpe, Lintner e Mossin}

O Modelo de Precificação de Ativos Financeiros (MPAF), mais conhecido como CAPM (Capital Asset Price Model), foi desenvolvido pelos estudos clássicos de Sharpe (1964), Lintner (1965) e Mossin (1966). A visão é, em diversos aspectos, complementar, o que acabou por permitir a construção do respectivo modelo. Seguindo a ordem cronológica de surgimento dos trabalhos, o primeiro autor a debater este assunto foi Sharpe (1964) (embora Lintner (1965) argumenta que concluiu seus estudos em 1964, antes da publicação de Sharpe, defendendo dessa forma que ele não teve influência dos estudos de Sharpe (1964)).

Sendo considerado um importante autor da Moderna Teoria de Finanças, Sharpe (1964) se fundamenta em Markowitz (1952) quando diz que qualquer investidor apenas obterá uma maior expectativa de retorno caso ele decida por correr um risco adicional. Ou seja, a relação risco-retorno será responsável por decidir até que ponto o investidor está propenso a se arriscar em função de quanto ele espera ganhar.

Dentro desta relação, o mercado apresentará então ao investidor dois prêmios: price of time: o retorno livre de risco (neste caso, mesmo que não se possa afirmar categoricamente, o investidor não está buscando um retorno alto, tendo em vista que o mesmo não está tão disposto a correr riscos); e o price of risk: a expectativa de retorno adicional por unidade de risco incorrido (neste caso, o investidor já está mais 
propenso a risco, esperando um retorno acima do normal). Se os dois prêmios forem combinados, uma reta é formada. Esta reta é chamada de Capital Market Line (CML).

Ainda se baseando em Markowitz (1952), Sharpe sabe que a diversificação de ativos em um portfólio irá reduzir o risco, logo, o risco total de um ativo não exerce influência relevante sobre seu preço, mas e o risco sistêmico (não diversificável) de cada ativo? A resposta para esta pergunta pode ser encontrada usando os conceitos da Fronteira Eficiente de Markowitz (1952), com algumas considerações propostas por Sharpe (1964). Sharpe (1964) inclui a possibilidade de se investir em um ativo 'livre de risco', associado com qualquer um dos portfólios contidos na Fronteira Eficiente. Isto irá gerar um portfólio dominante, conhecido como Portfólio Tangente, que formará uma linha tangente na Fronteira Eficiente encontrada.

Ao tratar do equilíbrio no mercado de capitais, Sharpe (1964) assume dois importantes pressupostos: há uma taxa que é livre de risco e ela é comum a todos os investidores, que podem aplicar ou obter um empréstimo em condições similares; e as expectativas dos investidores são homogêneas. Sabendo que esta generalização pode ocasionar várias críticas, Sharpe (1964) reconhece que tais pressupostos não são tão realistas, entretanto, o autor defende que esta simplificação não anula o modelo.

Considerando, desta forma, um mercado em equilíbrio, os ativos que não estão na Fronteira Eficiente têm seus preços diminuídos, o que eleva suas expectativas de retorno para que eles passem a se tornar atraentes aos investidores, abrindo a possibilidade da criação de novos portfólios eficientes, de maneira que todos os ativos tendam a linearidade, que é a CML. De qualquer forma, isto não significa que todos os investidores teriam o mesmo portfólio, ao contrário, já que na CML existem várias combinações de ativos distintas. O que existirá será uma relação linear simples entre a expectativa de retorno e o desvio padrão do retorno para as combinações eficientes de ativos de risco.

Quando se combina um ativo isolado com um portfólio eficiente de ativos, o risco sistêmico é encontrado, que é o risco que não pode ser reduzido utilizando a diversificação. Este risco será o coeficiente de inclinação, representado pelo símbolo $\beta$, da reta de regressão que pode ser obtida quando se insere em um gráfico os pontos indicativos dos retornos do ativo isolado em relação ao portfólio.

Pode-se perceber então que os ativos que mais irão influenciar um retorno do portfólio (que são os que possuem um maior coeficiente de inclinação) irão gerar uma maior expectativa de retorno, o que culminará na redução de seus preços. Lintner (1965) pretende analisar os preços de ações das empresas em conjunto com as escolhas feitas pelos investidores, levando em consideração a expectativa de retorno e o risco que está presente em cada ativo.

O valor de mercado de uma empresa é definido pela capitalização, por uma taxa livre de risco, de um equivalente de certeza da distribuição de probabilidade de retorno para todos os acionistas. Este equivalente de certeza pode ser definido como a expectativa de valor dos retornos indefinidos reduzindo um termo de ajustamento proporcional ao seu risco agregado, isto para cada empresa. Se o equilíbrio de mercado for considerado tal como nos estudos de Sharpe (1964), o fator proporcionalidade é o mesmo para todas as empresas. 
Em Markowitz (1952), o risco dos ativos era descoberto calculando-se o desvio padrão dos mesmos. Agora, o risco passa a ser calculado pela soma de sua variância e da covariância total com todos os outros ativos. Para Lintner (1965), a Taxa Mínima de Atratividade (TMA) estabelecida para admitir projetos de investimento arriscados seria uma função que possui cinco fatores: a taxa de retorno 'livre de risco' (ou o price of time (SHARPE, 1964)); o preço de mercado por risco (price of risk (SHARPE, 1964)); a variância do retorno de valor presente do projeto; a covariância do valor presente do projeto com ativos que a empresa já possui; e a covariância total com outros projetos que estão em andamento incluídos no orçamento de capital.

Resgatando a discussão da seleção de portfólios ótimos, iniciada por Markowitz (1952), Lintner (1965) assume alguns pressupostos quando esta seleção é realizada por um investidor individual: cada investidor pode aplicar parte de seu capital em um ativo livre de risco; pode investir qualquer fração do seu capital em qualquer ou em todos os ativos de risco; são tratados em um único mercado puramente competitivo, livre de custos de transações e impostos, que consequentemente não dependem da quantidade investida. Ele também assume que qualquer investidor pode, se desejar, pegar capital emprestado para se investir em ativos arriscados; e finalmente o investidor faz qualquer operação em datas discretas e não contínuas.

Com uma visão um pouco mais ampliada do que havia sido explanado por Sharpe (1964), Lintner (1965) avalia o retorno de um ativo como a adição dos dividendos recebidos junto da variação no valor de mercado do ativo. $\mathrm{O}$ autor pondera ainda que o investidor deverá optar por um portfólio com maior retorno para um respectivo nível de risco, ou um menor risco para um nível de retorno esperado. Tal assertiva vai depender do perfil do investidor, se este é propenso, indiferente ou avesso ao risco.

Tal como já observado em Sharpe (1964), Lintner (1965) considera que o retorno líquido de investimento esperado está diretamente relacionado com o risco. Dessa forma, na medida em que o investidor aumenta sua expectativa de retorno, maior será o risco assumido por ele. Para Lintner (1965), existe um portfólio que maximiza o retorno pelo risco aceito.

Como uma união dos estudos de Markowitz (1952) e Sharpe (1964) aos estudos de Lintner (1965), cria-se a chamada Market Opportunity Line. Esta 'linha' pode ser obtida adicionando ao modelo de Fronteira Eficiente a taxa livre de risco, considerando um mercado perfeito para empréstimos. A Market Opportunity Line, que parte da taxa livre de risco, é a tangente da Fronteira Eficiente, tocando apenas um local em toda fronteira. O local tocado por esta linha é o único portfólio ótimo considerado, em uma situação onde não se aplica ou toma emprestado à taxa livre de risco. Este conceito acaba por remeter a uma visão semelhante à de Sharpe (1964), quando ele apresenta o conceito de Portfólio Tangente.

Em relação ao pressuposto de que há uma relação linear entre a expectativa de retorno e sua variância, Lintner (1965) o anula apresentando o conceito de Strictly Linear Indifference Contour (Contorno Indiferente Estritamente Linear) entre a expectativa de retorno e a variância de um ativo individual. Ele apresenta que as covariâncias com outros ativos são constantes, o que sugere que as proporções de todos os ativos no portfólio também são inalteradas. 
Finalmente, Mossin (1966) também foi responsável por importantes contribuições para a formulação do CAPM. Ele inicia seu trabalho fazendo referência aos trabalhos que já haviam sido desenvolvidos sobre mercado de capitais que relacionavam risco e retorno, com destaque para os trabalhos de Markowitz (1952) e Tobin (1959). Para Mossin (1966), este assunto era tratado de forma generalizada em todos estes trabalhos, o que fatalmente implicava em uma certa superficialidade, tendo em vista que as simplificações quase sempre se originam de pressupostos restritivos. Tal assertiva então remetia uma crítica aos estudos passados ${ }^{2}$.

Independente de tecer algumas críticas aos trabalhos de Markowitz (1952) e Tobin (1959), pela generalidade contida nos pressupostos do trabalho, Mossin (1966) também assume alguns pressupostos: o rendimento de um ativo é aleatório com uma distribuição que é conhecida pelos indivíduos, já que todos eles possuem a mesma percepção das probabilidades da distribuição; o rendimento de todo portfólio pode ser considerado aleatório; e os indivíduos decidem pelos melhores portfólios guiados apenas pela expectativa de retorno e variância.

Além disso, Mossin (1966) discute o diagrama média-variância, apresentado originalmente por Markowitz (1952). Para o autor, este diagrama faz sentido apenas nas situações em que tanto as médias quanto as variâncias estão relacionadas com alguma unidade compartilhada para todos os ativos, como por exemplo, um valor monetário de investimento. Para Mossin (1966), será impossível para algumas realocações aumentar a utilidade de um indivíduo sem ao mesmo tempo reduzir a utilidade de um ou mais indivíduos. Este equilíbrio de alocação de ativos representa um ótimo de Pareto³

Normalmente, a taxa de retorno de um ativo é considerada como se fosse dividida em duas partes: a taxa livre de risco adicionada do prêmio pelo risco (ou price of risk, conforme apresentado por Sharpe (1964)). Levando em conta que o mercado define apenas o preço do ativo relativo, significa que a taxa pura de retorno não é definida pelo mercado. Dessa forma, o mercado estabelece apenas o price of risk (ou a margem de risco).

O price of risk pode ser compreendido de maneira mais clara utilizando-se da análise da taxa de substituição entre a expectativa de retorno e risco no equilíbrio. A especificação desta taxa de substituição converge na existência de uma 'Curva de Mercado', já tratada por Sharpe (1964) e Lintner (1965), como Capital Markel Line (uma linha em um plano entre a média e o desvio padrão, com a linearidade entre os ativos).

Entretanto, a CML dependerá completamente do comportamento do investidor, que deverá por sua vez ser racional. Ela irá apenas sumarizar o resultado deste comportamento racional, pois irá apresentar as condições do mercado em equilíbrio, sendo o mercado estabelecido em termos de condições implícitas de que os indivíduos buscam maximizar sua função de utilidade. Caso aconteça de algum indivíduo não agir racionalmente, tanto o conceito de equilíbrio, quanto o de Capital Market Line, perdem seu significado, pois a análise é completamente invalidada.

\footnotetext{
${ }^{2}$ Jan Mossin é um dos poucos Europeus (Norueguês) dentre os autores clássicos trabalhados na Moderna Teoria de Finanças, que tem sua base toda delineada nos Estados Unidos.

${ }^{3}$ Solução Eficiente ou Ótimo de Pareto - solução baseada no consenso entre as múltiplas funções. 
Mesmo sabendo deste entrave, Mossin (1966) trabalha com este conceito afirmando que o preço do risco irá representar a inclinação da CML, algo que já havia sido apresentado por Sharpe (1964) e também por Lintner (1965). Tendo então como base os estudos explorados (SHARPE, 1964; LINTNER, 1965; MOSSIN, 1966), foi desenvolvido e consolidado o modelo CAPM. Ao considerar $\beta$ o "coeficiente beta da ação", Rf o "retorno livre de risco" e Rm o "retorno da carteira de mercado", o CAPM pode ser demonstrado por meio da seguinte expressão: $E\left(R_{i}\right)=R f+\beta\left(R_{M}-R_{f}\right)$.

O que faz do modelo CAPM um dos mais famosos e mais usados no mundo é a simplicidade de sua expressão, que o torna mais acessível em comparação com outros modelos. Adicionalmente, o fato de trabalhar tanto com o risco diversificável quanto com o risco não diversificável representam um grande diferencial, principalmente porque ele permite avaliar o risco não diversificável e com isso, gerenciá-lo. Outro modelo clássico que merece ser estudado é o Modelo de Precificação por Arbitragem, ou APT (Arbitrage Pricing Theory), por meio dos estudos de Ross (1976) e também de Roll et al. (1980).

\section{A Hipótese dos Mercados Eficientes e seus reflexos na Moderna Teoria de Finanças}

A Hipótese dos Mercados Eficientes (HME) é uma teoria que se inicia nos estudos clássicos de Eugene Fama em 1970. Nesta primeira obra, Fama (1970) apresenta como os mercados se tornam eficientes na medida em que acompanham todas as informações geradas e que estão disponíveis para todos os investidores. Esta teoria volta a ser tratada e atualizada 21 anos depois, pelo próprio Fama (1991). Além disso, um estudo de Stephen Brown, em 2011, apresenta uma revisão das obras de Fama após a crise de 2008, em que várias críticas foram realizadas aos economistas e à Hipótese de Mercados Eficientes. Ao se analisar o preço de equilíbrio das ações, percebe-se que sua formação reflete o consenso entre todos os investidores. As variações, que representam grandes riscos no mercado financeiro (MARKOWITZ, 1952), ocorrem, na maioria dos casos, de acordo com as informações que são repassadas ao mercado.

Nota-se então que estas informações possuem uma grande responsabilidade no que se refere ao aumento ou na diminuição da demanda por determinadas ações, tendo em vista se as informações são positivas ou negativas no que se refere as respectivas ações (FAMA, 1970). Tal assertiva é responsável pela criação do termo 'Mercado Eficiente', quando o preço dos papéis reflete as informações disponíveis aos investidores do mercado. Entretanto, se este preço não refletir as informações disponíveis aos investidores, o mercado será então considerado um 'Mercado Ineficiente'.

Em um estudo posterior, Fama (1991) adverte que os preços refletem as informações até o ponto em que os benefícios da ação sobre a informação não exceda os custos marginais. As condições de equilíbrio do mercado são demonstradas de acordo com o retorno esperado de cada um dos títulos, com uma análise em função dos riscos. Para Fama (1970), existem três formas (testes) de eficiência dos mercados:

Fraca: Esta forma de eficiência apresenta que o preço das ações irá refletir de acordo com todas as informações que estão disponíveis no mercado, incluindo os movimentos históricos dos papéis, assim como os volumes de negociação. Desta maneira, os retornos passam a ocupar também um patamar de previsibilidade que esteja de acordo com as informações que estão disponíveis; 
Semiforte: Nesta forma de eficiência, o consenso é de que os preços de forma eficiente se ajustam diante de outras informações que estão à disposição pública, que são (além das informações contidas na eficiência de forma fraca) desdobramentos, anúncios de ganhos anuais, noticiários, etc.; e

Forte: Na forma forte de eficiência, além de refletir todas as informações da forma semiforte, se testa a existência (ou não) de informações privilegiadas (Inside Information), que são fundamentais para formação de qualquer preço. Caso exista, é realizado um questionamento a respeito da origem destas informações: É de dentro da companhia? Quem possuía estas informações? Porque elas não se tornaram públicas?.

Fama (1970), demonstra seu modelo por meio de equações para comprovar a teoria da Hipótese dos Mercados Eficientes, considerando as informações disponíveis como parâmetro para a conclusão das equações. Outras questões também são apresentadas no que se refere aos mercados eficientes, com destaque para os Modelos 'Fair Game', 'Randon Walk' e 'Submartingale'. No 'Fair Game', ou Jogo Justo, os retornos esperados de um amplo número de observações são constituídas por meio de um padrão histórico, que é observado e acreditado pelos investidores. Entretanto, os resultados futuros são, de certa forma, imponderáveis, seguindo então rumos aleatórios, o que define o segundo modelo, chamado de 'Randonwalk', ou Passeio Aleatório.

A sequência 'Submartingale' presume que o valor de uma observação seja maior ou igual ao valor esperado da última observação. Todo estudo desenvolvido em 1970 é revisado 21 anos depois, pelo próprio Fama, que passa a considerar as várias contribuições que vieram posteriormente ao seu primeiro trabalho. Mesmo sendo importante estas atualizações, sobretudo quando realizadas pelo próprio autor, Fama (1991) ressalta que normalmente a revisão não fica tão boa quanto o original.

Apoiando-se em trabalhos já publicados, Fama (1991) aponta a pesquisa de Grossman et al. (1980). Nesta pesquisa, Grossman et al. (1980) analisa que uma precondição da Hipótese de Mercados Eficientes é que os custos de transação e os cursos de obtenção das informações sejam sempre zero. Outro autor (clássico) referenciado nesta pesquisa é Jensen (1978), que afirma que os preços refletem as informações até o ponto em que os benefícios marginais da informação são extrapolados pelos custos que são envolvidos nas operações. Ainda que acreditasse ser muito difícil inferir sobre o grau de eficiência do mercado, Fama (1991) admite o grande valor do tema a respeito do nosso entendimento do comportamento dos retornos dos ativos de risco.

Uma das principais mudanças do artigo de 1970 para o artigo de 1991 é a alteração das categorias de forma de eficiência do mercado, já apresentadas anteriormente. No artigo de 1991, a forma de eficiência Fraca é alterada para Teste de Previsibilidade dos Retornos, incluindo também variáveis como, por exemplo, dividendos e taxas de juros. As formas de eficiência Semiforte e Forte sofrem apenas uma alteração em seus nomes, sendo a Semiforte agora chamada de Estudos de Eventos e a Forte de Teste de Informações Privativas. Entretanto, nota-se que em termos de nomenclatura, nada adiantou, pois continua se usando apenas as antigas nomenclaturas para se referir as respectivas formas de eficiência.

Aprofundando no novo Teste de Previsibilidade de Retornos, Fama (1991) deseja responder se a previsibilidade dos retornos reflete uma variação racional por meio do tempo nas expectativas de retorno ou desvios irracionais dos preços (ou até mesmo uma combinação entre as duas). Em seu estudo, Fama (1991) 
cita diversos estudos que efetuaram o respectivo teste e a conclusão geral foi a de que os retornos diários e semanais podem ser previstos pelos retornos passados, derrubando consequentemente a Hipótese de Mercado Eficiente. Contudo, o efeito das variações diárias e semanais na expectativa do retorno (pelo menos no que se refere aos ativos individuais) é uma parte pequena da variância dos retornos.

Devem-se citar os trabalhos de Shiller (1984) e Summers (1986), que segundo Fama (1991) chegaram à conclusão de que a previsibilidade dos retornos é baixa em curto prazo, todavia, quando se considera o longo prazo, o teste demonstra alta previsibilidade. No entanto, os estudos de Fama junto de French, em 1988, constataram que quando se usa períodos entre 3 ou 5 anos, o tamanho da amostra diminui e com isso, se reduz o poder de explicação do modelo. Outros testes também evidenciaram um poder de previsibilidade pequeno no longo prazo (FAMA et al., 1988).

A partir do momento em que se considerou no estudo outras variáveis, foi possível concluir que há uma correlação entre variações frequentes nas expectativas de retorno e nas condições de mercado. Isto significa que bolhas frequentes em diferentes mercados se relacionam diretamente com as condições de mercado.

Para Fama (1991), tendo como premissa o tema central, em que as variações nas expectativas de retorno são racionais, de nada ajudou os testes de volatilidade que foram desenvolvidos com o intuito de mostrar que a expectativa de retorno é constante e que a variação no valor das ações são fornecidas integralmente pelas modificações nas expectativas dos dividendos. Uma anomalia do passado que não se repete no futuro por ser encarada, a princípio, como uma ineficiência de mercado, mas se considerarmos esta assertiva como verdade absoluta, não iremos considerar o aprendizado dos investidores que enfrentaram tal anomalia. Ou seja, até as situações imponderáveis influenciam o comportamento futuro do mercado.

Fazendo uma associação com contribuições passadas, de Sharpe (1964), Lintner (1965) e Mossin (1966), responsáveis pela construção do CAPM, Fama (1991) apresenta vários estudos que rejeitam o CAPM, situação que ele considera normal. Para ele, o modelo de múltiplos fatores (APT) é melhor que o modelo CAPM. Entretanto, o autor ressalta que as rejeições ao CAPM nunca são claras o suficiente, tendo em vista que a proxy usada para representar a carteira de mercado pode ter sido mal construída.

No que se refere ao Teste das Informações Privativas (antiga forma forte de eficiência), estudos demonstraram que não existem investidores que possuem informações privativas, por outro lado, alguns estudos demonstraram que gestores de fundos e gestores internos das organizações possuíam sim, informações privilegiadas.

Como estudo clássico mais atual, está a pesquisa de Brown (2011), que complementa tudo o que foi debatido nos estudos de Fama (1970; 1991). Brown faz uma releitura dos artigos de Fama tendo como base o contexto pós-crise de 2008. Nele, observam-se várias críticas referentes a Hipótese do Mercado Eficiente. Tal como Fama, Brown (2011) também cita o trabalho de Gossman et al. (1980), que alega que se os respectivos valores refletem toda a informações disponível, não há necessidade para se adquirir novas 
informações. Entretanto, considerando uma visão mais econômica, a informação passa a ser importante quando seu custo será menor que o retorno marginal.

Brown (2011) apresenta que outros autores também questionam a Hipótese dos Mercados Eficientes. A premissa para os questionamentos estão no fato de que se os mercados são eficientes e as informações estão todas disponíveis, não existe maneira de existir formação de bolhas. Com isso, pequenos investidores (que possuem capital limitado tal como as informações), podem vir a assumir a Hipótese de Mercado Eficiente como uma descrição da maneira como os mercados funcionam, algo que, obviamente, não acontece na prática.

Pode-se comprovar tal assertiva comparando a situação acima com a crise de 2008 , que causou grande impacto nos Estados Unidos. Ancorados pela Hipótese do Mercado Eficiente, os profissionais que atuavam no mercado de capitais e os homens públicos "acreditavam" que a bolha financeira não era uma ameaça real, pois com o tempo, o mercado se autorregularia. Além disso, eles acreditavam que todas as informações disponíveis no mercado estariam refletidas nos preços das ações. Quatro anos após o fato, foi possível constatar que as coisas não ocorreram desta forma, principalmente se quando se considera que foi preciso intervenções explícitas do estado no mercado financeiro. Logo, a Hipótese do Mercado Eficiente não indica se uma bolha está se formando e muito menos quando ela irá estourar.

O conceito de 'Random Walk' (ou Passeio Aleatório) também é resgatado por Brown (2011). Para o autor, as informações repassadas não formam expectativas confiáveis. Ele defende que o Randon Walk não é a Hipótese do Mercado Eficiente, pois as alterações nas expectativas dos retornos durante certo tempo, por motivo das alterações nas informações, acaba sendo um problema apenas para o Randon Walk, mas não para a Hipótese do Mercado Eficiente.

Analisando sobre um aspecto contemporâneo, Brown (2011) menciona que poucas pessoas acreditam na hipótese do mercado eficiente, e deixa uma provocação no ar, querendo saber se realmente a queda da credibilidade na Hipótese do Mercado Eficiente foi, de fato, a responsável pelas últimas crises financeiras. Embora ainda existam outros artigos clássicos com evidências empíricas que poderiam ser estudados (FAMA et al., 1988, 1996; LIM et al., 2011), a análise destes artigos clássicos consolida a teoria da Hipótese de Mercados Eficientes, desde sua concepção até sua aplicação na atualidade.

\section{A quebra de paradigmas e o nascimento das finanças comportamentais}

O desenvolvimento dos estudos das finanças comportamentais surge como uma significativa quebra de paradigmas para a área. Antes da criação e difusão da referida teoria, apenas cálculos estatísticos, matemáticos e econométricos eram levados em consideração, entretanto, dois psicólogos israelenses da Universidade Hebraica de Jerusalém mudaram a história. Amos Tversky e Daniel Kahneman ${ }^{4}$ mostraram que a heurística pode ser um grande aliado nas decisões de incerteza. O primeiro estudo em que este tema apareceu foi o estudo Judgment under Uncertainty: Heuristics and Biases, de 27 de Setembro de 1974. No referido artigo, os autores enfatizam os vieses e heurísticas que afetam o decision maker (tomador de

\footnotetext{
${ }^{4}$ Vale a pena ressaltar que Kahneman afirma nunca ter feito qualquer cadeira em economia.
} 
decisão), quando ele se depara com alguma situação de incerteza. Amos Tversky e Daniel Kahneman fazem então menção a três heurísticas:

Heurística da representatividade, que é normalmente empregada quando pessoas são questionadas para julgar a probabilidade que um objeto ou evento $A$ pertence a uma classe ou processo $\mathrm{B}$;

Heurística da disponibilidade de instancias ou cenários, que é frequentemente empregada quando as pessoas são questionadas para avaliar a frequência de uma classe ou plausibilidade de um desenvolvimento particular; e

Heurística do ajustamento e ancoragem, que é comumente empregada em uma predição numérica quando um valor relevante está disponível. (KAHNEMAN et al., 1974)

Os estudos de Kahneman et al. (1974) demonstraram que não são em todas as situações que os investidores se mantêm racionais, principalmente quando se deparam com uma situação de tomada de decisões envolvendo riscos. Além disso, eles apresentam vieses cognitivos que tem origem na confiança em heurísticas de julgamento e que são aplicadas para acionar probabilidades e presumir valores.

Até pela formação base dos autores e pelo interesse inicial de pesquisa, pode-se observar uma grande influência da psicologia que permeia todo o trabalho. Um exemplo interessante é a questão da comparação do número de fazendeiros e bibliotecários: É fato que se possui no mundo mais fazendeiros que bibliotecários. Por esta lógica, Steve será um fazendeiro. Entretanto, a estatística não tem condições de afirmar este resultado, pois é necessário se observar também o perfil psicológico de Steve, que pode demonstrar que ele tem mais habilidades para se tornar um bibliotecário.

A demonstração anterior da preocupação com o perfil do indivíduo para se chegar à conclusão de qual profissão ele pode exercer remete a um posicionamento Interpretativista, dentro dos paradigmas apresentados por Burrell et al. (1979). Embora o texto não apresente esta perspectiva, a área de Finanças, que sempre foi taxada de Funcionalista, passa agora a ter um viés Interpretativista meio aos estudos das Finanças Comportamentais, representando uma marcante quebra de paradigmas.

Por meio de vários testes e comprovações científicas, Kahneman et al. (1974) mostra que os homens tomam muitas decisões por serem oportunistas: “Dick é um Engenheiro ou um Advogado?". Quando se apresenta uma lista contendo vários nomes e se pergunta qual se a maioria é de engenheiros ou advogados, se o entrevistado for engenheiro, dirá que são de engenheiros, se o entrevistado for advogado, dirá que são advogados, ou seja, existem associações para tomada de decisões que até então não eram consideradas, tendo em vista que não está se falando de máquinas, e sim de seres humanos. Os estudos apresentam claramente que o homem é produto do meio, tal como na assertiva de Berger et al. (1985).

Outra inferência interessante se diz respeito aos padrões de comportamento. Normalmente as pessoas são propensas a acreditar que um padrão de comportamento tende sempre a se repetir. Se uma pessoa ganha na loteria, acertando 6 dezenas, no outro dia, milhares de pessoas jogam as mesmas 6 dezenas. Esta questão se relaciona no jogo 'cara ou coroa'. A maioria das pessoas tende a acreditar que haverá alternâncias quase que linear entre a parte da frente e a parte de trás da moeda, o que não necessariamente vai acontecer. Tendo em vista que pessoas tomam decisões baseados nestas premissas, é muito importante tentar mapear e prever estes tipos de comportamentos, sobretudo nas situações de incertezas. 
Kahneman et al., 1974 afirmam que as pessoas têm maior confiança em fazer previsões quando os pontos de análise obedecem a um padrão. Além disso, eles apresentam que situações que ocorrem com mais frequência tem mais chance de serem certas do que casos que acontecem com menor frequência. Entretanto, a disponibilidade é afetada por fatores além da frequência e das probabilidades (KAHNEMAN et al., 1974).

Uma outra situação que deve ser considerada na tomada de decisão é o fato do cérebro em alguns momentos tomar decisões visando o menor esforço e que nem sempre são as melhores para aquele momento. Como exemplo, se faz os seguinte questionamento: 'Existem mais palavras no dicionário Inglês iniciando com a letra ' $R$ ' ou que possuem a letra ' $R$ ' como a terceira letra?'. Por ser mais fácil pensar em palavras que se iniciam com a letra ' $R$ ' ao invés de palavras que tem a letra ' $R$ ' como a terceira letra (dicionário inglês), a maioria das pessoas acredita erroneamente que existem mais palavras iniciando com a letra ' $R$ '.

Esta questão de se apostar na "pior" opção é apresentada pelos autores em diversos casos, mostrando a fragilidade dos seres humanos na tomada de decisões. Esta inclusive é uma das críticas feitas às ferramentas de análise de risco, que em várias situações faz com que os tomadores de decisões fiquem descrentes com as orientações, tendo em vista que tais ferramentais se referem, na maioria dos casos, a estruturas disjuntivas (menos escolhidas) (KAHNEMAN et al., 1974).

Além deste estudo, outros estudos de Kahneman et al. (1974), ora trabalhando em conjunto, ora trabalhando com outro co-autor, representam um importante papel para o avanço das finanças comportamentais, sendo sugerido para futuras explanações. Estudos clássicos como Kahneman et al. (1979), que lhe concedeu o prêmio Nobel em economia, podem contribuir para o aprofundamento deste tema.

Finalmente, Kahneman et al. (1974) deixa no ar uma provocação que desperta (na época) as mais variadas críticas no que se refere aos estudos das Finanças. Eles dizem que pessoas que conhecem estatísticas muito bem, conseguem fazer boas previsões, mas e aquelas previsões que as estatísticas não medem? Tal questionamento serve apenas para solidificar ainda mais a importância deste novo e fundamental caminho na Moderna Teoria de Finanças.

\section{As contribuições de Jensen, Meckling e Myers para a Teoria dos Conflitos e os Custos de Agência}

Considerada uma das teorias clássicas da Moderna Teoria de Finanças, está a teoria do conflito e dos custos de agência. Para composição desta teoria, estão presentes estudos clássicos de importantes autores, como Jensen et al. (1976), Myers (1977) e finalmente Jensen (1986) em um trabalho independente. Pode-se observar grande influência dos estudos de Modiglini et al. $(1958,1963)$ para desenvolvimento desta importante teoria.

Inicialmente, em um importante trabalho desenvolvido em conjunto, Jensen et al. (1976) estão contextualizados em um cenário de recentes avanços em teorias de direitos de propriedade, da agência e de finanças como um todo. A moderna teoria de finanças passa a se solidificar cada vez mais. Por este motivo, os autores fundamentam-se sobre a separação de propriedade e controle da empresa, responsabilidade social, a função objetiva corporativa, a determinação de uma estrutura ótima de capital, entre outros aspectos. 
De forma geral, a Teoria da Firma é conhecida como um contrato sob o qual uma ou mais pessoas (que recebem o papel de 'principal'), contrata outra pessoa (que será o 'agente') para desempenhar alguma função que envolva poder e tomada de decisões (JENSEN et al., 1976). Entretanto, esta teoria apresenta uma série de problemas de inadequação, sobretudo ligados a teoria do relacionamento da agência. Estes problemas existem porque o relacionamento da agência incorre em custos, e para maximizar a utilidade dos dois (agente e principal), o agente nem sempre agirá conforme os interesses do principal.

Um dos principais aspectos que podem ser mapeados é o fato de que o agente obtém benefícios não exclusivamente financeiros durante a sua permanência na condição supracitada, o que, em alguns momentos, diverge integralmente dos interesses dos investidores. O principal tenta, dessa forma, limitar o agente, mas incorre em custos de monitoramento, concessão de garantias contratuais, custos residuais, dentre outros.

Os custos de monitoramento, neste caso, teriam como função o controle das ações adotadas pelos agentes, e se materializam em auditorias, sistemas de controle ou outros procedimentos correlatos. Estes gastos geram custos aos investidores externos, que tendem a pagar menos pelas ações da companhia. Neste caso, o agente pode estabelecer padrões de gastos com os investidores, e elevar o valor de mercado da empresa. No entanto, ele só faria isso caso o aumento do Valor de Mercado compensasse os benefícios individuais de que ele abriu mão.

Jensen et al. (1976) entra em um assunto já tratado por Modigliani et al. $(1958,1963)$, que é a questão do índice de alavancagem de uma organização. Jensen et al. (1976) expõe as razões para não se ter uma empresa com $100 \%$ de dívidas, quais sejam as imposições de credores sobre limites de endividamento, os custos de falência que limitam a alavancagem (apesar dos benefícios fiscais proporcionados).

Os autores concluem ainda, que quanto maior a empresa, maiores os custos de agência. Desta forma, o proprietário deveria investir os seus recursos na empresa, e somente caso necessário, contratar capital externo. No entanto, isso diminui a diversificação, (que tem um papel fundamental para se aumentar o lucro e se diminuir o risco, segundo Markowitz (1952)) e aumenta a exposição ao risco. Frequentemente, estabelece-se um trade-off ${ }^{5}$ entre a diminuição de risco e o aumento de custos de agência.

Myers (1977), por sua vez, complementa os estudos previamente desenvolvidos por Jensen e Meckling (1976). No caso se Myers, o foco é nos determinantes dos empréstimos coorporativos. O objetivo é tentar entender por que algumas empresas fazem mais empréstimos do que outras, por que alguns empréstimos são de curto prazo, outros são de longo prazo, e assim por diante. Tal como explanado anteriormente, este estudo também se embasa nas obras de Modigliani e Miller, sobretudo nos estudos de 1963, em que os autores apresentam que as empresas precisam manter uma reserva de capacidade de endividamento (MODIGILIANI et al., 1963).

Modigiliani et al. (1963) apresenta que para as empresas, é racional limitarem o seu endividamento, mesmo quando há interesse em deduções fiscais. Suas teorias apresentam que é possível existir uma forma de racionamento de capital pelos credores, inclusive nestas situações. A partir de então, é especificada uma 
característica de ativos que estimulam o alto endividamento, que não é de baixo risco. Suas teorias explicam também vários fenômenos que até o momento não haviam sido estudados, como por exemplo, o motivo das empresas tenderem a 'combinar as maturidades' dos vencimentos de ativos e obrigações de dívidas.

A teoria apresentada por Myers (1977) está embasada em um argumento relativamente simples. Ela inicia apresentando que a maioria das empresas são avaliadas com certo índice de preocupação, tendo em vista que a incerteza sempre norteia todas as ações no mercado financeiro. As avaliações das empresas refletem uma expectativa de investimento futuro continuado pela empresa. Entretanto, qualquer investimento é praticado com total liberdade de escolha, logo, a quantidade investida dependerá dos valores presentes e principalmente das oportunidades que aquela empresa poderá gerar no futuro. Dependendo da situação em que a empresa se encontrará no futuro, pode-se parar de investir por completo na mesma.

Além disso, outro conceito é apresentado nos estudos de Myers (1977). Uma empresa com dívida de risco, e que atua no interesse de seus acionistas, seguirá uma regra de decisão diferente da empresa que pode emitir dívidas sem risco ou até mesmo não emitir nenhuma dívida. No caso da empresa financiada com dívidas de risco, elas podem, em algumas oportunidades, deixar passar investimentos valiosos, que poderiam aumentar o valor de mercado da empresa, pois as dívidas de risco podem vir a afastar tais investimentos.

Citando Jensen et al. (1976), Myers (1977) apresenta que os argumentos do estudo são semelhantes aos que foram trabalhados pelos autores na análise de custos de agência e da estrutura ótima de capital. Entretanto, os estudos de Jensen et al. (1976) não reconhecem o custo particular relacionado à política de investimento sub-ótima, que é um custo de agência induzida pela dívida de risco. Jensen et al. (1976) trabalham a teoria de estrutura ótima de capital com base em diferentes fenômenos, conforme descrito anteriormente.

Vale à pena ressaltar que a teoria apresentada por Myers (1977) baseia-se em certas imperfeições específicas no mercado de opções reais. Neste caso, é necessário que o valor desta opção desapareça ou diminua se ela não for exercida pela empresa. Esta suposição pode ser justificada das seguintes maneiras: as opções reais podem ser específicas da respectiva empresa, não tendo nenhum valor para qualquer outra empresa; se as opções reais não são específicas da respectiva empresa, contudo, elas podem ser negociadas em mercados secundários (imperfeitos).

Os estudos de Makowitz (1952), também estão presentes na teoria proposta por Myers (1977), atestando mais uma vez o motivo de Markowtiz ser considerado o 'pai' da Moderna Teoria de Finanças. 0 autor defende a diversificação dos ativos, dizendo que uma das vantagens alegadas da diversificação corporativa é que as empresas diversificadas podem realizar mais empréstimos. A combinação de ativos com menores retornos perfeitamente correlacionados fornece uma taxa de variação para o valor da combinação que é menor que do que a taxa média dos ativos considerados separadamente, tal como havia sido desenvolvido por Markowitz (1952).

Finalmente, Michael Jensen retorna em um estudo independente, no ano de 1986, complementando tudo o que havia sido feito dentro do tema Conflitos e Custos de agência. Em seu estudo, ele apresenta os Custos de agência de Fluxo de Caixa Livre, as Finanças Corporativas e Aquisições. O relacionamento entre 
agentes e principais é fundamentado em grande conflito de interesses (JENSEN et al., 1976). A análise destes conflitos passa então a ser um ponto comum em grande parte da literatura da época. Jensen (1986) conclui que o pagamento dos acionistas com dinheiro faz com que se aumente a necessidade de capital externo, e consequentemente uma maior monitoração do mercado. Quando uma empresa financia os projetos internamente, ela evita esta monitoração.

O conflito de interesses, por sua vez, norteia o estudo proposto por Jensen (1986). A partir desta premissa, a teoria desenvolvida por Jensen (1986) explica: os benefícios da dívida na redução dos custos de agência e de fluxo de caixa; como a dívida pode substituir para os dividendos; porque os programas de diversificação são mais propensos a gerar perdas do que as aquisições ou expansões na mesma linha de negócios ou em aquisições motivadas por liquidações; porque os fatores que geram a aquisição em atividades diversas, como radiodifusão e indústria de tabaco são similares a indústria do petróleo; e, finalmente, porque os proponentes (e algumas de suas metas) tendem a se comportar de forma anormal ante as aquisições.

A partir de então, o autor passa a apresentar o papel das dívidas para motivar a Eficiência operacional. Este papel recebe o nome de 'hipótese do controle', porém, ele conclui dizendo que isto não garante que a hipótese do controle terá sempre efeitos positivos. Em empresas de grande crescimento ou lucro, isto não acontece. Por este motivo, a hipótese de controle funciona de maneira mais assertiva em empresas com pequenos índices de crescimento, tendo em vista que nestas empresas, o desperdício do fluxo de caixa é sempre mais sério.

Posteriormente, o estudo apresenta várias evidências que norteiam o assunto, a começar pela Evidência da reestruturação financeira, seguido da Evidência de alavancagem e das transações privadas, e finalmente a Evidência da indústria do petróleo, ao qual ele explora com mais detalhes, já que esta indústria foi uma que, devido a vários acontecimentos, acabou por encolher em determinado período da história.

Quando se analisa especificamente a indústria do petróleo, percebe-se que os gerentes utilizaram da diversificação para se investir em várias indústrias fora da indústria do petróleo, como por exemplo: indústrias do varejo, de manufatura e de equipamentos de escritório e manutenção. Jensen (1986) também apresenta os resultados das aquisições na indústria do petróleo. As uniões de várias empresas, como por exemplo, Getty e Texaco, trouxeram ganhos potenciais em torno de US\$17bi.

Embasado nestas situações, o autor desenvolve e apresenta a Teoria do Fluxo de Caixa Livre em relação às aquisições. $\mathrm{O}$ autor demonstra que embora as indústrias de tabaco lucrem muito, elas estão "impedidas" de crescer, pois a cultura da população em relação ao consumo do cigarro está mudando, dessa forma, seria uma prática recomendada aproveitar os retornos favoráveis e investir em outros setores.

Mesmo com toda contribuição acima relatada, Jensen (1986), conclui este estudo dizendo que ele descobriu que ainda existem dados que são incompatíveis com a teoria apresentada, e que estes dados estão sendo testados. Por fim, o tema Conflitos e Custos de Agência representa um dos principais temas da moderna teoria de finanças. Para estudos futuros, outros temas complementares e trabalhos clássicos podem ser explorados, como o tema Assimetria Informacional (ROSS, 1977; MYERS et al., 1984; RAJAN et al., 
1995) e o tema Hierarquia das Fontes de Financiamento no Contexto da Simetria Informacional (LELAND et al., 1977; MYERS et al., 1984; MILLER et al., 1985).

\section{CONCLUSÕES}

A partir dos estudos de Markowitz (1952), muitas foram às contribuições para a evolução da Moderna Teoria de Finanças, que culminaram nos clássicos da área. Tais estudos se pautaram em maneiras de se diminuir as incertezas, escolher a melhor forma se realizar os investimentos e maximizar os lucros das organizações.

Para alcançar estes resultados, foram desenvolvidas uma série de fórmulas matemáticas e econométricas, que aplicadas a determinadas situações, poderiam apresentar as conclusões desejadas. Embora os estudos matemáticos representem um fator preponderante para os resultados financeiros de qualquer organização, a influência das relações humanas e o papel do indivíduo neste processo passam a se solidificar cada vez mais.

Em situações envolvendo o principal e o agente (JENSEN et al., 1976) pode-se notar que tais conflitos também se tangenciam no que se refere às relações sociais entre ambos os papeis. Isto demonstra que além de se estudar as maneiras de se otimizar investimentos por meio das teorias supracitadas, estudos embasando também as relações interpessoais entre estes dois papéis pode agregar bastante nesta área, que é vasta e ainda possui muito o que ser explorado.

A quebra de paradigma proveniente dos estudos em Finanças Comportamentais (TVERSKY e KAHNEMAN, 1974) abre espaço para um novo campo de estudo dentro da (até então) tradicional área das finanças. Embora os modelos matemáticos e econométricos prevaleçam, há espaço para o nascimento de vários trabalhos (que podem vir a se tornar clássicos) pautados em aspectos até então inexplorados.

Finalmente, revisitar os clássicos em Finanças comprova a transformação sofrida pela área em função do tempo. E esta transformação apresenta a todos os pesquisadores e interessados, que esta área, tida como tradicional durante vários anos, está agora aberta a novas ideias, a novos paradigmas e a todos os tipos de contribuições.

\section{REFERÊNCIAS}

ANGELO, H.; MASULIS, R. W.. Optimal Capital Structure under corporate and personal taxation. Journal of Financial Economics, v.8, p.3-29, 1980.

BERGER, P. L.; LUCKMANN, T.. A Construção Social da Realidade: Tratado de Sociologia do Conhecimento. Petrópolis: Vozes, 1985.

BROWN, S. J.. The efficient markets hypothesis: The demise of the demon of chance? Accounting and Finance, v.51, p.79-95, 2011.

BURREL, G.; MORGAN, G.. Sociological paradigms and organizations analysis. London: Heinemann, 1979.
CALVINO, I.. Por que ler os clássicos. São Paulo: Companhia das Letras, 2007.

FAMA, E. F.. Efficient Capital Markets: A Review of Theory and Empirical Work. Journal of Finance, v.25, n.2, p.383-417, 1970.

FAMA, E. F.. Efficient Capital Markets: II. Journal of Finance, v.46, n.5, p.1575-1617, 1991.

FAMA, E. F.; FRENCH, K. R.. Dividend yields and expected stock returns. Journal of Financial Economics, v.22, n.1, p.3-25, 1988. 
FAMA, E. F.; FRENCH, K. R.. Multifactor Explanations of Asset Pricing Anomalies. Journal of Finance, v.51, n.1, p.55-84, 1996.

FARRELL JUNIOR, J. L.. Portfolio management. 2 ed. New York: McGraw-Hill, 1997.

GIL, A. C.. Métodos e Técnicas de Pesquisa Social. São Paulo: Atlas, 1995.

IQUIPAZA, R. A.; AMARAL, H. F.; BRESSAN, A. A.. Evolução da Pesquisa em Finanças: Epistemologia, Paradigmas e Críticas. Revista O\&S: Organizações e Sociedade, v.16, n.49, p.351-370, 2009.

JENSEN, M.. Agency Costs of Free Cash Flow, Corporate Finance, and Takeovers. The American Economic Review, Washington, v.76, n.2, p. 323-360, 1986.

JENSEN, M.. Some anomalous evidence regarding market efficiency. Journal of Financial Economics, Elsevier, v. 6, n.3, p.95-101, 1978.

JENSEN, M.; MECKLING, W.. Theory of the firm: managerial behavior, agency costs and ownership structure. Journal of Financial Economics, p.305-360, 1976.

KAHNEMAN, D.; TVERSKY, A.. Prospect Theory: An Analysis of Decision under Risk. Econometrica, v.47, n.2, p.263-292, 1979.

LELAND, H.; PYLE, D.. Informational asymmetries, financial structure and financial intermediation. Journal of Finance, v.32, n.2, p.317-87, 1977

LIM, K.; BROOKS, R.. The evolution of stock market efficiency over time: A survey of the empirical literature. Journal of Economic Surveys, v.25, n.1, p.69-108. 2011.

LINTNER, J.. The Valuation of risk assets and the selection of risky investments in stock portfolios and capital budgets. The Review of Economics and Statistics, v.47, n.1, p.13-37, 1965.

MARKOWITZ, H.. Portfolio Selection. Journal of Finance, v.7, n.1, p.77-91, 1952.

MILLER, M. H.. Debt and Taxes. Journal of Finance, v.32, p.261-75, 1977.

MILLER, M. H.. The Modigliani-Miller Propositions after thirty years. Journal of Economic Perspectives, v.2, n.4, p.99-120, 1988.

MILLER, M. H.; MODIGLIANI, F.. Dividend Policy, growth and the valuation of shares. Journal of Business, v.34, p.411-433, 1961.
MILLER, M. H.; ROCK, K.. Dividend Policy Under Asymmetric Information. Journal of Finance, v.40, n.4, p.1031-1051, 1985.

MINAYO, M. C. S.. O desafio do conhecimento: pesquisa qualitativa em saúde. 5 ed. São Paulo: Hucitec-Abrasco, 1998.

MODIGLIANI, F. MILLER, M. H.. The Cost of Capital, Corporation Finance, and the Theory of Investment. The American Economic Review, v.48, n.3, p.261-97, 1958

MODIGLIANI, F.; MILLER, M. H.. Corporate income taxes and the cost of capital correction. The American Economic Review, v.53, n.3, p.433-443. 1963.

MOSSIN, J.. Equilibrium in a Capital Asset Market. Econometrica, v.34, n.4, p.768-783, 1966.

MYERS, S. C.. Determinants of corporate borrowing. Journal of Financial Economics, v.5, p.147-175, 1977.

MYERS, S. C.; MAJLUF, N.. Corporate financing and investment decision when firms have information investors do not have. Journal of Financial Economics, v.13, n.2, p.187-221, 1984

RAJAN, R. G.; ZINGALES, L.. What do We Know about Capital Structure? Some Evidence from International Data. Journal of Finance, v.50, p.1421-1460, 1995.

ROLL, R.; ROSS, S. A.. An Empirical Investigation of the Arbitrage Pricing Theory. Journal of Finance, v.35, n.5. p.1073-1103, 1980.

ROSS, S. A.. The Arbitrage Theory of Capital Asset Pricing. Journal of Economic Theory, v.13, n.3, p.34160, 1976.

ROSS, S. A.. The Determination of Financial Structure: The Incentive-Signalling Approach. The Bell Journal of Economics, v.8, n.1, p.23-40. 1977

SHARPE, W. F.. Capital Asset Prices: A Theory of Market Equilibrium under Conditions of Risk. Journal of Finance, v.19, n.3, p.425-442, 1964.

SHILLER, R. J.. Stock prices and social dynamics. Brookings Papers on Economic Activity, v.2, p.457510, 1984,

SUMMERS, L. H.. Does the stock market rationally reflect fundamental values?. Journal of Finance, v.41, p.591-601, 1986.

TOBIN, J.. Liquidity Preference as Behavior Towards Risk. Review of Economic Studies, v.67, 1959. 
TVERSKY, A.; KAHNEMAN, D.. Judgment under Uncertainty: Heuristics and Biases. Science, v.185, p.1124-1131. 1974.
WOOLRIDGE, J. R.; GHOSH, C.. Dividend cuts: do they always signal bad news?. Midland Corporate Finance Journal, v.3, n.2, p.20-32, 1985.

YIN, R. K.. Case study research: design and methods. Beverly Hills: Sage, 1989. 